\title{
A taxonomic study of Korean Juncus based on the anatomical characters
}

\author{
Chang-Seok Jang and Byoung-Un $\mathrm{Oh}^{1}{ }^{\text {* }}$ \\ Forest Biodiversity Division, Korea National Arboretum, Pocheon 11186, Korea \\ ${ }^{1}$ Department of Biology, Chungbuk National University, Cheongju 28644, Korea \\ (Received 18 October 2016; Revised 14 November 2016; Accepted 12 December 2016)

\section{한국산 골풀속의 해부학적 형질에 의한 분류학적 연구 \\ 장창석 - 오병운 ${ }^{*}$ \\ 국립수목원 산림생물조사과, ${ }^{1}$ 충북대학교 생물학과}

\begin{abstract}
The anatomical characters of the 19 taxa of Korean Juncus were reviewed in order to examine their significance in taxonomy. Cross-section analyses were conducted on the stem, leaf, and capsule. Descriptions, line drawings, tables, and a species key of Korean Juncus are provided for species identification based on anatomical characters. The results of this study showed that the arrangements of the vascular bundle, fiber, and air-space structure in the stems as well as the arrangements of the vascular bundle and parenchyma in the leaves and the development of placenta in capsules are the key characters to be used when classifying each species of Juncus. It was revealed that the studied anatomical features were more useful for identification at the subgenera and section levels than at the species level. Therefore, these anatomical characters used in conjunction with external morphological features will make a valuable contribution to establishing a natural classification system for Juncus.
\end{abstract}

Keywords: Juncus, anatomy, taxonomy, cross section, classification system

적 요: 한국산 골풀속 19 분류군에 대하여 해부학적 형질의 유용성을 검토하고자 연구를 수행하였다. 줄기, 잎, 삭과 등을 횡단하여 관찰하였으며, 주요 형질을 도해하고, 기재하였다. 또한 해부학적 형질에 근거한 검 색표를 작성하였고, 분류군간 차이점을 표로 제시하였다. 연구 결과, 줄기의 유관속, 섬유, 기도의 배열양상 과 잎의 형태, 유관속 및 유조직의 배열양상, 삭과에서 태좌의 발달정도 등의 형질들이 골풀속 식물의 분류 에 매우 유용한 것으로 확인되었다. 그러나 일부 분류군에서는 근연 분류군과의 분류형질로 유용한 것으로 밝혀졌지만, 종 수준보다는 절 또는 아속 수준의 분류에 더 유용한 것으로 확인되었다. 따라서 해부학적 형 질은 다른 외부형태학적 형질과 더불어 보다 자연적인 분류체계 설정에 기여할 수 있을 것이라 판단되었다.

주요어: 골풀속, 해부, 분류, 횡단, 분류체계

골풀속(Juncus L.)은 골풀과(Juncaceae)에 속하는 식물군 으로서 약 300 분류군이 전세계적으로 널리 분포하며, 북 서아메리카, 지중해 연안, 중국-히말라야(Sino-Himalayan) 지역, 극동아시아, 남아프리카, 오스트랄라시아 등지에 집중적으로 자생한다(Wu and Clemants, 2000; Kirschner et al., 2002; Novikov, 2003).
본 속에 대한 고전적인 연구로는 Linnaeus (1753)가 최초 로 15 종을 기재한 이래, Laharpe (1825)가 상세 기재문을 포 함하여 78종을 기록하면서 점차 알려지게 되었다. Buchenau $(1875,1890,1906)$ 는 외부형태학적 형질을 기준으 로 전 세계 골풀과에 대한 종합적인 연구를 수행하였으며, 골풀속 170 여 분류군을 8 개 아속으로 구분하여 분류체계

*Author for correspondence: obutaxon@chungbuk.ac.kr 
에 대한 기틀을 확립하였다. 이후 Kirschner 등 (2002)은 이 전까지 기록된 전 세계 골풀속 식물 약 315 분류군을 정리 하였으며, 속 내 2아속 10절로 분류계급을 설정한 바 있다.

한국산 골풀속에 대한 연구는 R. Oldham이 채집한 표본 (no. 895)을 바탕으로 Miquel (1867)이 J. communis var. japonicus Miq.를 신변종으로 발표한 것이 최초의 보고이 다. 이후 Buchenau (1890), Palibin (1901), Léveillé (1904), Nakai (1911, 1952), Satake (1938), Chung (1956, 1965, 1970), Lee (1980), Lee (1996a, 1996b), Oh와 Lee (2007) 등이 도감 등에 분포 목록 및 기재를 서술하였으며, $\mathrm{Kim}$ 와 $\mathrm{Ko}$ (1980), Oh (1984)에 의해 한반도 내 골풀과의 분포가 정리 된 바 있다. 최근 Kim et al. (2012)과 Yun 등 (2014)이 검정 납작골풀(J. fauriei Lév. \& Vaniot)을 미기록종으로, 김의골 풀(J. baekdusanensis M. Y. Kim)을 신종으로 각각 발표하였 으며, Jang (2008), Kim (2012), Kim and Kim (2013) 등은 한 국산 일부 분류군들에 대한 분류학적 연구를 시도하였다.

한편 골풀속 식물을 분류하는 데 유용한 특징으로는 화서의 배열, 형태, 소포의 존재 유무, 화피 및 삭과의 길이, 모양, 선단부의 형태 등 생식형질뿐만 아니라 지하경의 길 이, 잎 및 줄기의 형태 등의 영양형질도 매우 중요하게 사 용되고 있다. 특히 줄기, 잎, 삭과 등의 해부학적 형질들은 건조된 표본에서도 뚜렷하게 관찰되기 때문에 지속적인 연구가 수행되어 왔다. Satake (1931a, 1931b, 1932, 1933a, 1933b, 1933c, 1933d, 1934)는 일본산 골풀속 식물을 대상으 로 과피의 발달정도와 종피의 미세구조, 기공의 돌출정도 에 대한 해부학적 연구를 수행하였으며, Cutler (1969)는 골 풀목의 해부학적 연구에서 골풀속 29 분류군의 잎, 줄기, 뿌 리, 지하경 등의 표피형, 횡단면을 도해·기재하였고, 표피 세포의 크기, 기공의 분포양상, 줄기와 잎에서 후벽세포와 기도, 엽록조직, 유조직의 분포양상이 가지는 분류학적 중
요성을 시사하였다. 또한 Fernández-Carvajal (1981, 1982a, 1982b, 1983)과 Fernández-Carvajal et al. (1989)은 이베리아반 도에 생육하는 골풀속 분류군들에 대한 줄기와 잎의 횡단 면과 표피형에 대한 해부학적 연구를 진행하였다.

그러나 이러한 해부학적 형질의 중요성에도 불구하고, 현재까지 한국산 골풀속에 대해서는 해부학적 연구가 수 행된 바 없다. 따라서 저자들은 본 연구를 통하여 한국산 골풀속의 잎, 줄기, 삭과의 해부학적 형질들을 관찰하고, 이들 형질들의 분류학적 유용성에 대해 논의하고자 연구 를 수행하였다.

\section{재료 및 방법}

본 연구는 표본 및 현지 조사를 통해 한반도 내에서 자 생이 직접 확인된 19 분류군을 대상으로 하였다(Kirschner et al., 2002; Jang, 2016). 구름골풀(J. triglumis L.), 설령골풀 [J. castaneus subsp. triceps (Rostk.) Novikov], 대택비녀골풀 [J. stygius subsp. americanus (Buchenau) Hultén], 백두실골 풀(J. potaninii Buchenau), 갯골풀(J. haenkei E. Mey.), 참골 풀(J. filiformis L.) 등의 북한 분포 식물들은 서울대학교 생 물학과 표본관(SNU), 국립수목원 표본관 $(\mathrm{KH})$, 동경대 표 본관(TI) 등의 표본을 통해 분포를 확인하였으며, 중국의 장백산을 비롯하여 몽골, 일본 등에서 수집한 재료를 실 험에 사용하였다.

연구에 사용된 재료는 2002년부터 2014년까지 국내·외 에서 채집된 개체이며, 개화기와 결실기를 중심으로 채 집하여 건조표본 또는 $70 \%$ ethanol에 고정하여 액침표본 으로 제작하였다. 각 표본들은 충북대학교 생물학과 식 물표본실(CBU)에 보관하였으며(Table 1), 일부는 충북대 학교 생물학과 온실 및 실험포장에 이식·재배하여 생활

Table 1. Materials and collection data of the genus Juncus in this study.

Taxon Collection site and date

\section{Subg. Juncus}

\section{A. Sect. Stygiopsis (Gand. ex) Kuntze}

1. J. triglumis L. 구름골풀

HB: Gwanmobong (19 Jul 1936)

Mongolia: Arhangai, Tsetseleg (25 Jul 2002)

2. J. maximowiczii Buchenau 실비녀골풀

3. J. potaninii Buchenau 백두실골풀

4. J. castaneus subsp. triceps (Rostk.) Novikov 설령골풀

GN: Jirisan, Cheonwangbong (10 Jun 2007)

China: Jilin, Baishan-shi, Mt.Chanbai (? 2014)

China: Jilin, Changbaisan (7 Aug 2014)

China: Jilin, Jangbaeksan, Bukpa (24 Jul 2007)

HB: Seollyeong (25 Jul 1918)
? 20961 (SNU)

S. H. Park $1096279(\mathrm{KH})$

C. S. Jang 49472 (CBU)

J. S. Lee s.n. (KH)

J. S. Lee s.n. $(\mathrm{KH})$

J. O. Hyeon 49006 (CBU)

T. Nakai 20963 (SNU)

5. J. stygius subsp. americanus (Buchenau) Hultén 대택비녀골풀

China: Jilin, Changbaisan (19 Jul 2014)

J. S. Lee s.n. $(\mathrm{KH})$ 
Table 1. Continued.

\begin{tabular}{|c|c|c|}
\hline Taxon & Collection site and date & Voucher \\
\hline \multicolumn{3}{|c|}{ B. Sect. Ozophyllum Dumort. } \\
\hline \multicolumn{3}{|c|}{$\begin{array}{l}\text { 6. J. prismatocarpus subsp. leschenaultii } \\
\text { (Laharpe) Kirschner 참비녀골풀 }\end{array}$} \\
\hline & JJ: Namwon-eup, Muryeongari (28 Jun 2007) & C. S. Jang 49743 (CBU) \\
\hline \multicolumn{3}{|c|}{ 7. J. alatus Franch. \& Sav. 날개골풀 } \\
\hline & JN: Gurye-gun, Jirisan (11 Jun 2007) & C. S. Jang 49733 (CBU) \\
\hline \multicolumn{3}{|c|}{ 8. J. diastrophanthus Buchenau 별날개골풀 } \\
\hline & GW: Yangyang-gun, Namdaecheon (10 Jul 2007) & C. S. Jang 49535 (CBU) \\
\hline \multicolumn{3}{|c|}{ C. Sect. Iridifolii Snogerup \& Kirschner } \\
\hline \multicolumn{3}{|c|}{ 9.J. wallichinaus J. Gay ex Laharpe 눈비녀골풀 } \\
\hline & JJ: Daejeong-eup, Gueok-ri (28 Jun 2007) & C. S. Jang 49803 (CBU) \\
\hline \multicolumn{3}{|c|}{ 10. J. papillosus Franch. \& Sav. 청비녀골풀 } \\
\hline & GB: Bonghwa-gun, Cheongoksan (23 Sep 2006) & C. S. Jang 49620 (CBU) \\
\hline 11. J. krameri Franch. \& & GW: Yangyang-gun, Namdae creek (18 Aug 2007) & C. S. Jang 49034 (CBU) \\
\hline
\end{tabular}

2. Subg. Aganthryon Raf.

D. Sect. Tenageia Dumort.

12. J. bufonius L. 애기골풀

E. Sect. Steirochloa Griseb.

GW: Yangyang-gun, Yeounpo (21 Jun 2012)

C. S. Jang 39076 (CBU)

13. J. tenuis Willd. 길골풀

CB: Cheongju-si, Chungbuk Univ. (8 Jun 2006)

C. S. Jang 49919 (CBU)

14. J. gracillimus (Buchenau) V. I. Krecz. \& Gontsch. 물골풀

\section{F. Sect. Juncotypus Dumort.}

JJ: Jocheon-eup, Sinheung-ri (29 Jun 2007)

C. S. Jang 49552 (CBU)

15. J. haenkei E. Mey. 갯골풀

Japan: Hokkaido, Nemuro (11 Aug 2012)

C. S. Jang 39041 (CBU)

HB: Seosura (4 Jun. 1930)

J. Ohwi 435 (TI)

16. J. fauriei Lév. \& Vaniot 검정 납작골풀

GW: Yangyang-gun, Yeounpo (21 Jun 2012)

C. S. Jang 39087 (CBU)

17. J. filiformis L. 참골풀

Japan: Hokkaido, Daisetsuzan, Sandanyama (8 Aug 2012) HN: Hamjiwon (16 Jul 1934)

C. S. Jang 39072 (CBU)

P. S. To s.n. (SNU)

18. J. decipiens (Buchenau) Nakai 골풀

CB: Goesan-gun, Jewol-ri (13 Jun 2005)

C. S. Jang 49507 (CBU)

19. J. setchuensis Buchenau 푸른갯골풀

CN: Taean-gun, Anmyeon-do (15 Jun 2007)

C. S. Jang 49725 (CBU)

Infrageneric classification based on Kirschner et al. (2002).

HB, Hamgyeongbuk-do; GN, Gyeongsangnam-do; JJ, Jeju-do; JN, Jeollanam-do; GW, Gangwon-do; GB, Gyeongsangbuk-do; CB,

Chungcheongbuk-do; HN, Hamgyeongnam-do; CN, Chungcheongnam-do.

사 및 성숙 시기에 따른 변화를 지속적으로 관찰하였다.

조직의 횡단면은 동일집단 내의 완전히 성숙하여 개화 한 개체를 대상으로 줄기, 잎, 열매의 일정 부위를 절취하 여 재료를 준비하였으며, 건조표본에서 채취한 시료는 짧 게 가열하여 조직을 복원하였다. 준비된 재료는 도수절편 으로 제작하여 관찰하거나, $70 \%$ alcohol에 고정한 후 alcohol series를 거쳐 paraffin에 포매하였고, 10-12.5 $\mu \mathrm{m}$ 로 절단하여 safranin-fast green으로 이중염색한 후 영구슬라
이드를 만들어 광학현미경(AX-70; Olympus, Tokyo, Japan) 으로 관찰·촬영하였으며, 주요 분류형질은 도해하였다. 줄기 및 잎의 도해도는 식물체의 다양한 크기 차이를 감 안하여 비율을 조정하여 제작하였으며, 분류군별로 각각 척도를 표시하였다. 또한 도해도 제작 시 참고한 영구슬 라이드의 이미지는 Jang $(2008,2016)$ 에서 확인 가능하다. 잎의 횡단면 관찰은 기본적으로 뚜렷한 경생엽을 가지는 분류군들을 대상으로 하였으며, 경생엽의 엽신 부분을 횡 
단하였다. 길골풀 (J. tenuis Willd.)의 경우 줄기의 마디에서 나오는 경생엽이 없고 기부엽만을 가지나, 기부엽은 다른 분류군의 경생엽과 마찬가지로 엽초와 엽신을 모두 가지 고 있는 형태로 관찰되므로 기부엽의 엽신 부분을 횡단하 였다. 또한 설령골풀의 경생엽은 단면엽이지만 줄기를 감 싸는 엽이 부분이 길게 신장되어 내권형(involute)처럼 보 이므로 경생엽 엽신의 중앙부와 납작한 형태의 정단부를 각각 관찰하였다.

관찰된 형질들을 근거로 줄기, 잎, 열매의 해부학적 특 성 등을 기재하였으며, 검색표를 제시하였다.

\section{결과 및 고찰}

\section{줄기의 횡단면(cross section of stem)}

줄기의 횡단면은 조직구성에 따라 유관속 및 섬유세 포의 배열 양상, 기도의 존재 유무 및 위치 등에서 분류군 별로 다양한 양상을 나타내었다(Fig. 1-3, Table 2).

\section{1. 표피(epidermis)}

표피는 1 층의 세포로 구성되어 있으며, 분류군에 따라 길이와 두께가 각각 5-15 $\mu \mathrm{m}$ 정도로 다양하게 나타났고, 세포 외곽으로 각피층(cuticular layer)이 발달하였다.

\section{2. 피층(cortex)}

줄기의 피층 부분은 세포함유물의 유무에 의해 엽록조직 과 일반적인 유조직으로 구분되었다. 세포함유물이 없는 유
조직(Fig. 1b)은 줄기 내부의 피층과 수를 구성하고 있으며, 피층유조직은 엽록조직과 섬유세포층 사이에 존재하였다.

\section{3. 엽록조직(chlorenchyma)}

표피 아래의 피층(cortex) 외곽에 존재하는 엽록조직 (Fig. 1d)은 피층을 구성하는 유조직의 일부이나, 세포함유 물의 차이에 의해 뚜렷이 구분되며, 분류군에 따라 1-7층 의 다양한 세포층을 가진 것으로 관찰되었다.

\section{4. 유관속(vascular bundle)}

산재유관속은 유관속의 내측에 목부(xylem)가 발달하 고, 외측에 사부(phloem)가 발달하는 병립유관속(collateral vscular bundles)의 형태를 보이며, 주축유관속의 경우 사 부나 목부에서 섬유조직이 발달하여 섬유층이 유관속을 둘러싸고 있는 형태로 관찰되었다. 또한 Subg. Agathryon 중 애기골풀(J. bufonius L.) (Fig. 3A)을 제외한 나머지 분 류군들인 길골풀(Fig. 3B), 물골풀[J. gracillimus (Buchenau) V. I. Krecz. \& Gontsch.] (Fig. 3C), 갯골풀(Fig. 3D), 검정납작 골풀(Fig. $3 \mathrm{E}$ ), 참골풀(Fig. $3 \mathrm{~F})$, 골풀 $[J$. decipiens (Buchenau) Nakai] (Fig. 3G), 푸른갯골풀(J. setchuensis Buchenau) (Fig. $3 \mathrm{H})$ 등의 경우 사부섬유가 비교적 심하게 발달하여 사부 를 완전히 둘러싸므로 주축유관속에서 사부와 목부의 명 확한 구분이 가능하였다. 한편 줄기에 날개가 발달하는 sect. Ozophyllum에 속하는 분류군들은 날개 부위에 작은 유 관속이 발달하였으며, 이들의 발달 정도는 잎의 너비에 비 례해서 별날개골풀(J. diastrophanthus Buchenau) (Fig. 2C)>

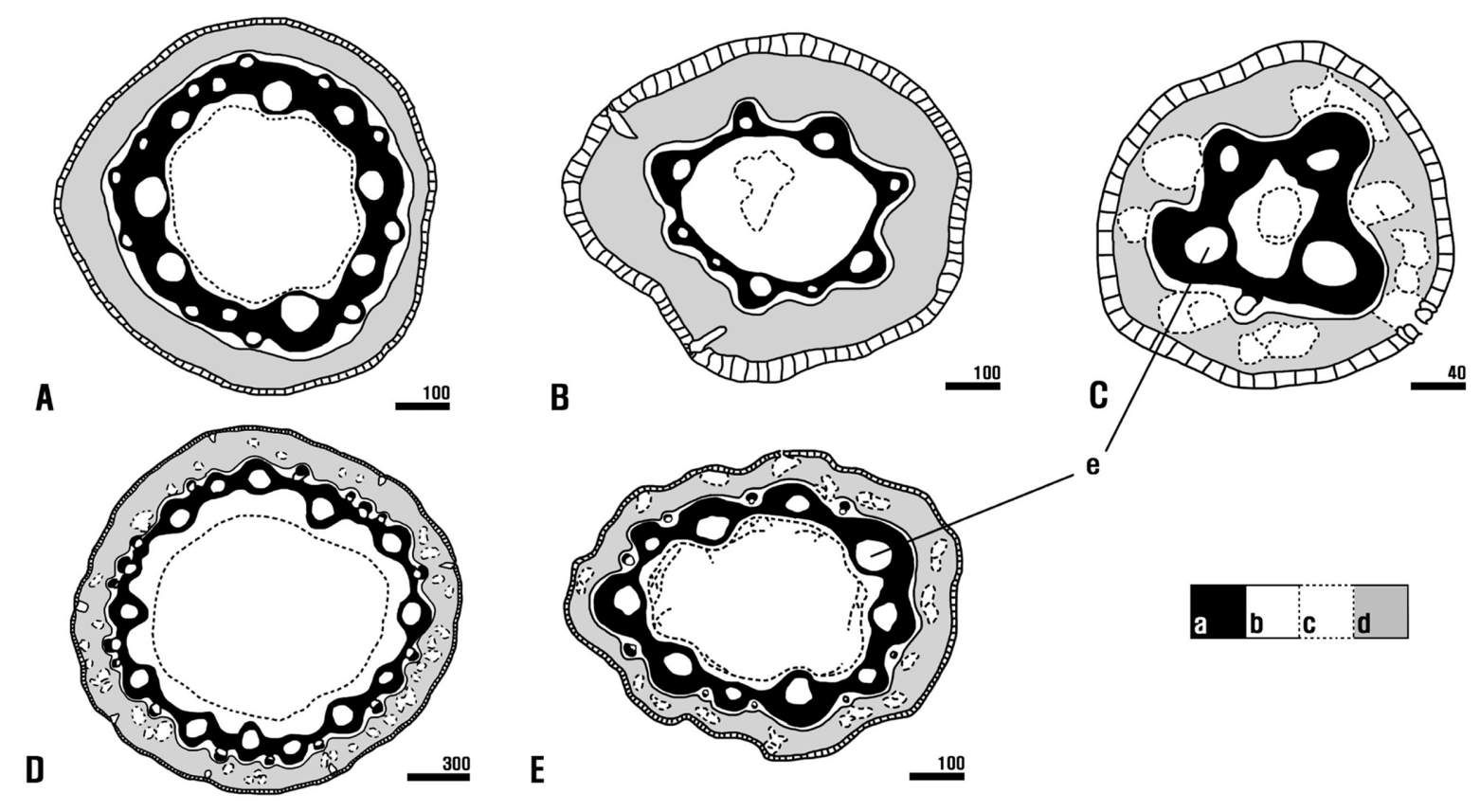

Fig. 1. Cross section shapes and structures of stem in Korean Juncus. A-E. sect. Stygiopsis; A. J. triglumis. B. J. maximowiczii. C. J. potaninii. D. J. castaneus subsp. triceps. E. J. stygius subsp. americanus. Scale bar unit: $\mu \mathrm{m}$. a, fibers; b, parenchyma; c, air-space; d, chlorenchyma; e, vascular bundle. The same explanatory notes apply to Figs. 1-5. 

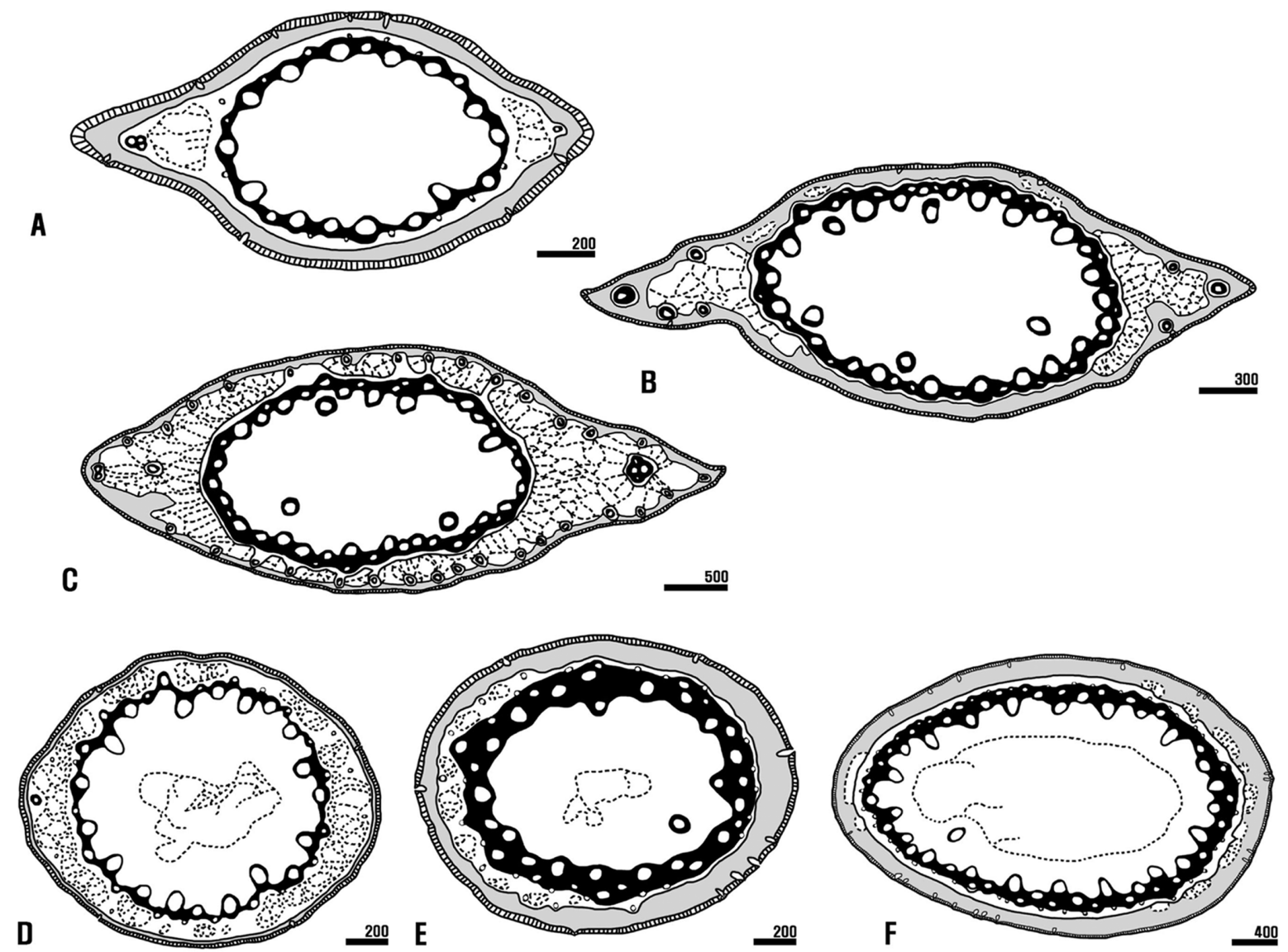

Fig. 2. Cross section shapes and structures of stem in Korean Juncus. A-C. sect. Ozophyllum. D-F. sect. Iridifolii. A. J. prismatocarpus subsp. leschenaultii. B. J. alatus. C. J. diastrophanthus. D. J. wallichianus. E. J. papillosus. F. J. krameri. Scale bar unit: $\mu \mathrm{m}$.

날개골풀(J. alatus Franch. \& Sav.) (Fig. 2B) > 참비녀골풀 $[J$. prismatocarpus subsp. leschenaultii (Laharpe) Kirschner] (Fig. 2A) 순으로 많아지는 것으로 나타났다.

\section{5. 섬유세포(fibers)}

줄기 내부에 존재하는 섬유세포는 후벽세포 (sclerenchyma cells)의 일종이며, 목전소(suberin)가 축적 된 이차벽(secondary wall)으로 유난히 두꺼워져서, 세포 내에 살아있는 원형질 부분이 없어지거나 지극히 좁게 남은 형태로 관찰된다. 골풀속에서 발달하는 섬유세포층 은 사부섬유, 목부섬유가 신장하여 발달된 것으로 여겨 지며, 유관속, 피층, 수 등에 무리로, 또는 여러 층으로 분 포하고, 섬유세포층의 배열양상에 따라 2 가지 유형으로 구분되었다.

\section{1) 환상형 (circular)}

유관속을 둘러싸는 목부섬유, 사부섬유와 이를 중심으 로 유관속 간에 발달한 섬유세포층이 환상으로 배열하는 형태로써 구름골풀(Fig. 1A), 실비녀골풀(J. maximowiczii Buchenau) (Fig. 1B), 백두실골풀(Fig. 1C), 설령골풀(Fig.
1D), 대택비녀골풀(Fig. 1E), 참비녀골풀(Fig. 2A), 날개골풀 (Fig. 2B), 별날개골풀(Fig. 2C), 눈비녀골풀(J. wallichianus J. Gay ex Laharpe) (Fig. 2D), 청비녀골풀(J. papillosus Franch. \& Sav.) (Fig. 2E), 비녀골풀(J. krameri Franch. \& Sav.) (Fig. 2F), 애기골풀(Fig. $3 \mathrm{~A})$, 길골풀(Fig. $3 \mathrm{~B}$ ), 물골풀 (Fig. $3 \mathrm{C}$ ), 갯골 풀(Fig. $3 \mathrm{D})$ 등에서 관찰되었다. 이러한 환상의 섬유세포 층은 유관속을 외부의 충격으로부터 좀 더 효율적으로 보호하고, 줄기를 지지하는 기능을 가질 것이라 여겨진 다(Jang, 2016).

\section{2) 비환상형(non-circular)}

유관속을 둘러싸며 발달하는 목부섬유와 사부섬유는 유관속간에 발달한 섬유세포층 없이 유관속만을 감싸고 있는 형태로써, 검정납작골풀(Fig. $3 \mathrm{E}$ ), 참골풀(Fig. $3 \mathrm{~F}$ ), 골풀(Fig. $3 \mathrm{G}$ ), 푸른갯골풀(Fig. $3 \mathrm{H})$ 등에서 확인되었다. 또한 골풀, 푸른갯골풀, 참골풀 등 3 종에서는 표피세포 아래에 후벽조직성의 섬유세포 무리가 산발적으로 존재 하였으며, 이들 섬유세포의 무리는 골풀에서는 유관속의 섬유세포 무리와 연결되어 있거나 독립적으로 존재하였 고, 푸른갯골풀과 참골풀에서는 독립적으로만 존재하는 
Table 2. Anatomical characters of the genus Juncus in Korea.

\begin{tabular}{|c|c|c|c|c|c|c|c|c|c|c|c|c|c|}
\hline \multirow[b]{2}{*}{ Taxa } & \multicolumn{5}{|c|}{ Stem } & \multicolumn{6}{|c|}{ Cauline leaf } & \multicolumn{2}{|c|}{ Fruit } \\
\hline & $\begin{array}{l}\text { Cross } \\
\text { section }\end{array}$ & $\begin{array}{l}\text { Vascular bundles } \\
\text { (PF. surrounded } \\
\text { VB.) }\end{array}$ & Fibers & $\begin{array}{c}\text { Subepidermal } \\
\text { sclenchyma } \\
\text { strands }\end{array}$ & Air canal & Leaf type & $\begin{array}{l}\text { Cross } \\
\text { section }\end{array}$ & VB. & $\begin{array}{l}\text { Parenchyma } \\
\text { (not } \\
\text { chlorenchyma) }\end{array}$ & Canaliculus & Septa & $\begin{array}{l}\text { Cross } \\
\text { section }\end{array}$ & Locular type \\
\hline J. triglumis & Terete & Not surrounded & Circular & Absent & Pith & Unifacial & $\begin{array}{l}\text { Terete } \\
\text { (groove) }\end{array}$ & Circular & Surrounded VB. & Bitubular & Imperfectly & Subdeltoid & $\begin{array}{l}\text { Pseudo } \\
\text {-trilocular }\end{array}$ \\
\hline J. maximowiczii & Terete & Not surrounded & Circular & Absent & Pith & Unifacial & $\begin{array}{c}\text { Subterete } \\
\text { (groove) }\end{array}$ & Circular & Surrounded VB. & Bitubular & Imperfectly & Orbicular & Unilocular \\
\hline$J \cdot$ potaninii & Terete & Not surrounded & Circular & Absent & $\begin{array}{c}\text { Pith } \\
\& \text { cortex }\end{array}$ & Unifacial & $\begin{array}{l}\text { Subterete } \\
\text { (groove) }\end{array}$ & Circular & Surrounded VB. & Bitubular & Imperfectly & Subdeltoid & $\begin{array}{l}\text { Pseudo } \\
\text {-trilocular }\end{array}$ \\
\hline $\begin{array}{l}\text { J. castaneus ssp. } \\
\text { triceps }\end{array}$ & Terete & Not surrounded & Circular & Absent & $\begin{array}{l}\text { Pith } \\
\& \text { cortex }\end{array}$ & Unifacial & $\begin{array}{l}\text { Involute } \\
\text { (apex: flat) }\end{array}$ & Circular & Surrounded VB. & Pluritubular & Imperfectly & Orbicular & $\begin{array}{l}\text { Pseudo } \\
\text {-trilocular }\end{array}$ \\
\hline $\begin{array}{l}J . \text { stygius ssp. } \\
\text { americanus }\end{array}$ & Terete & Not surrounded & Circular & Absent & $\begin{array}{l}\text { Pith } \\
\& \text { cortex }\end{array}$ & Unifacial & Subterete & Circular & Surrounded VB. & Pluritubular & Imperfectly & Subdeltoid & $\begin{array}{l}\text { Pseudo } \\
\text {-trilocular }\end{array}$ \\
\hline $\begin{array}{l}\text { J. prismatocarpus } \\
\text { ssp. leschenaultii }\end{array}$ & $\begin{array}{l}\text { Flat \& } \\
\text { winged }\end{array}$ & Not surrounded & Circular & Absent & Cortex & Unifacial & Flat & Circular & Surrounded VB. & Pluritubular & Imperfectly & Deltoid & Unilocular \\
\hline J. alatus & $\begin{array}{l}\text { Flat \& } \\
\text { winged }\end{array}$ & Not surrounded & Circular & Absent & Cortex & Unifacial & Flat & Circular & Surrounded VB. & Pluritubular & Imperfectly & Deltoid & Unilocular \\
\hline J. diastrophanthus & $\begin{array}{l}\text { Flat \& } \\
\text { winged }\end{array}$ & Not surrounded & Circular & Absent & Cortex & Unifacial & Flat & Circular & Surrounded VB. & Pluritubular & Imperfectly & Deltoid & Unilocular \\
\hline J. wallichianus & Terete & Not surrounded & Circular & Absent & $\begin{array}{c}\text { Pith } \\
\& \text { cortex }\end{array}$ & Unifacial & Terete & Circular & Surrounded VB. & Unitubular & Perfectly & Deltoid & Unilocular \\
\hline J. papillosus & Terete & Not surrounded & Circular & Absent & $\begin{array}{l}\text { Pith } \\
\& \text { cortex }\end{array}$ & Unifacial & $\begin{array}{l}\text { Subterete } \\
\text { (ridge) }\end{array}$ & Circular & Surrounded VB. & Unitubular & Perfectly & Deltoid & Unilocular \\
\hline J. krameri & Subterete & Not surrounded & Circular & Absent & $\begin{array}{l}\text { Pith } \\
\& \text { cortex }\end{array}$ & Unifacial & Subterete & Circular & Surrounded VB. & Unitubular & Perfectly & Deltoid & Unilocular \\
\hline J. bufonius & Terete & Not surrounded & Circular & Absent & Cortex & Bifacial & Involute & A line & Surrounded VB. & Air space & - & Orbicular & Trilocular \\
\hline J. tenuis & Terete & Surrounded & Circular & Absent & Absent & Bifacial & Involute & A line & $\begin{array}{c}\text { Some } \\
\text { surrounded VB. }\end{array}$ & Air space & - & Orbicular & $\begin{array}{l}\text { Pseudo } \\
\text {-trilocular }\end{array}$ \\
\hline J. gracillimus & Terete & Surrounded & Circular & Absent & Absent & Bifacial & Involute & A line & Surrounded VB. & Air space & - & Orbicular & $\begin{array}{l}\text { Pseudo } \\
\text {-trilocular }\end{array}$ \\
\hline J. haenkei & Terete & Surrounded & Circular & Absent & $\begin{array}{c}\text { Pith } \\
\& \text { cortex }\end{array}$ & - & - & - & - & - & - & Orbicular & $\begin{array}{l}\text { Pseudo } \\
\text {-trilocular }\end{array}$ \\
\hline J. fauriei & Subterete & Surrounded & $\begin{array}{l}\text { Non- } \\
\text { circular }\end{array}$ & Absent & $\begin{array}{c}\text { Pith } \\
\& \text { cortex }\end{array}$ & - & - & - & - & - & - & Orbicular & $\begin{array}{l}\text { Pseudo } \\
\text {-trilocular }\end{array}$ \\
\hline J. filiformis & Terete & Surrounded & $\begin{array}{l}\text { Non- } \\
\text { circular }\end{array}$ & Present & $\begin{array}{c}\text { Pith } \\
\& \text { cortex }\end{array}$ & - & - & - & - & - & - & Orbicular & $\begin{array}{l}\text { Pseudo } \\
\text {-trilocular }\end{array}$ \\
\hline J. decipiens & Terete & Surrounded & $\begin{array}{l}\text { Non- } \\
\text { circular }\end{array}$ & Present & $\begin{array}{c}\text { Pith } \\
\text { (spongy type) }\end{array}$ & - & - & - & - & - & - & Orbicular & Trilocular \\
\hline J. setchuensis & Terete & Surrounded & $\begin{array}{l}\text { Non- } \\
\text { circular }\end{array}$ & Present & $\begin{array}{c}\text { Pith } \\
\text { (spongy type) }\end{array}$ & ) & - & - & - & - & - & Orbicular & $\begin{array}{l}\text { Pseudo } \\
\text {-trilocular }\end{array}$ \\
\hline
\end{tabular}

PF, phloem fibers; VB, vascular bundles. 

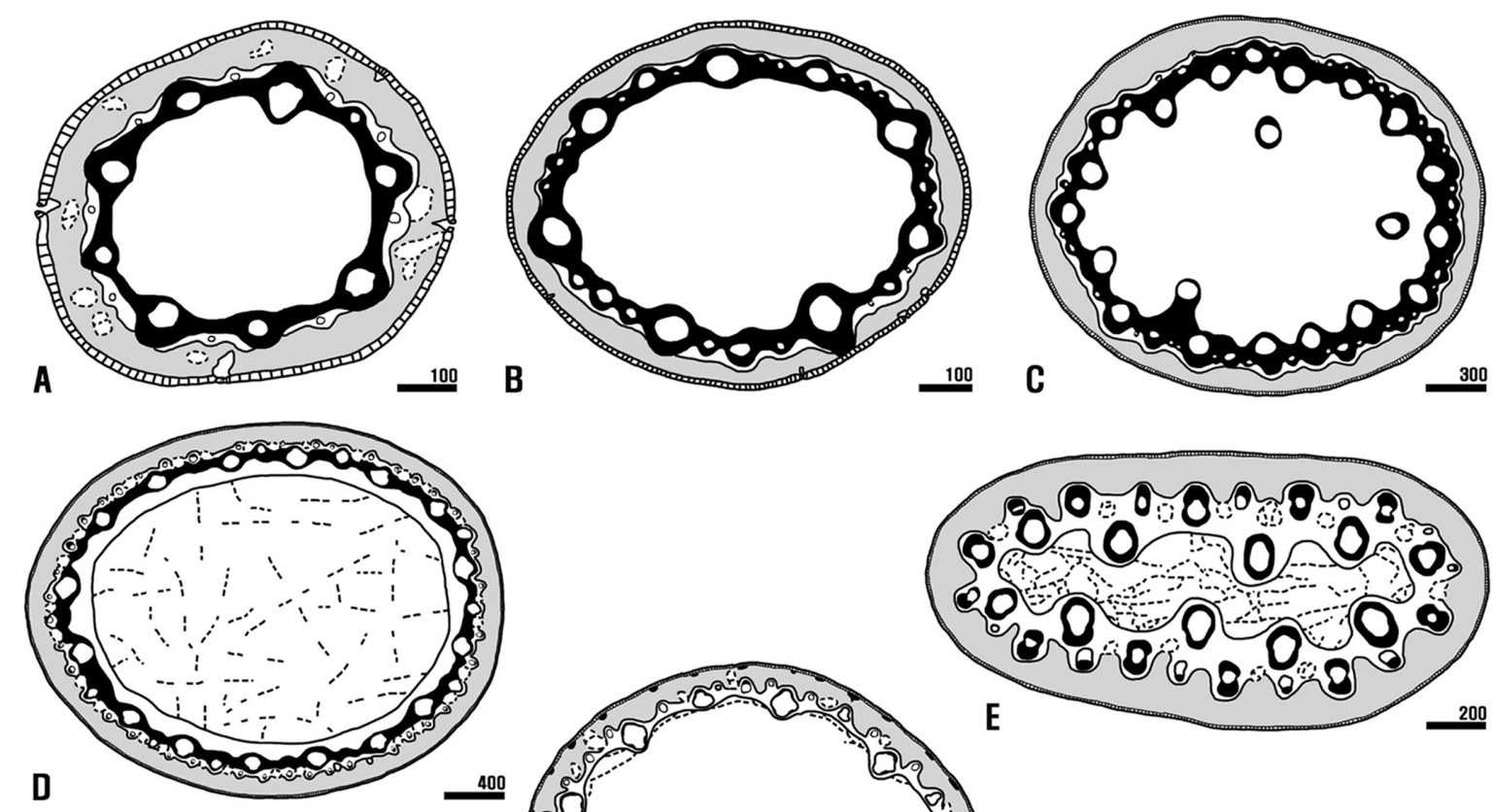

D

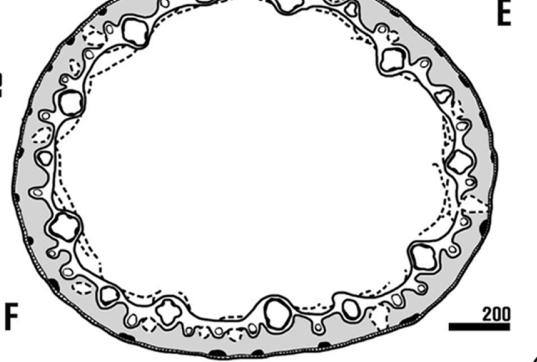

G
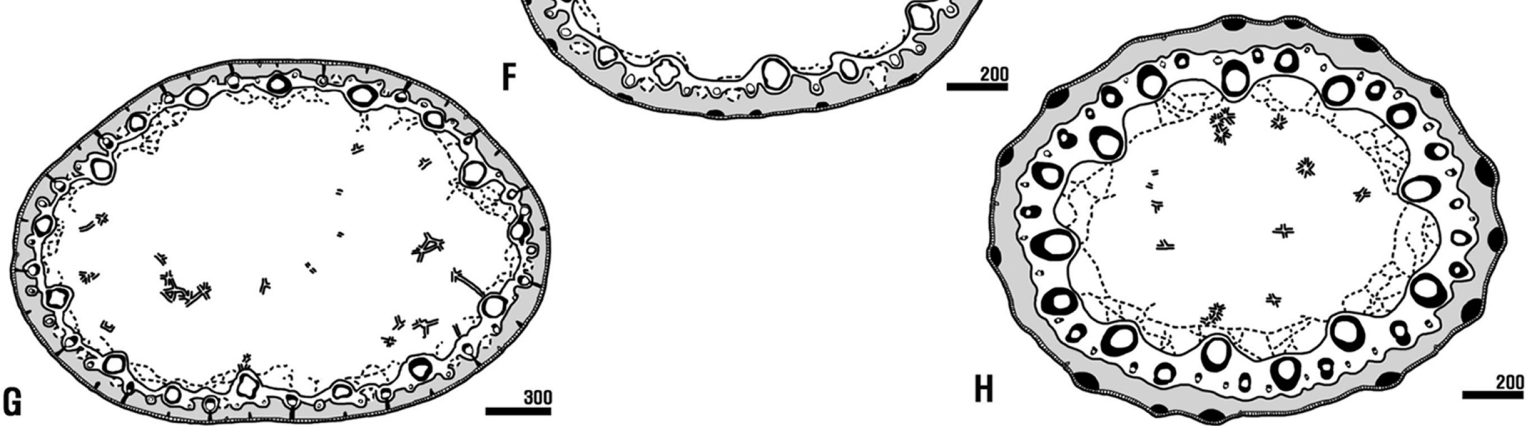

Fig. 3. Cross section shapes and structures of stem in Korean Juncus. A. sect. Tenageia. B, C. sect. Steirochloa. D-H. sect. Juncotypus. A. J. bufonius. B. J. tenuis. C. J. gracillimu. D. J. haenkei. E. J. fauriei. F. J. filiformis. G. J. decipiens. H. J. setchuensis. Scale bar unit: $\mu \mathrm{m}$.

차이점도 관찰되었다. 더불어 푸른갯골풀의 표피세포 아 래에 존재하는 섬유세포 무리는 골풀과 참골풀에 비해 다소 큰 형태로 존재하며, 외견상 뚜렷한 세로 능선으로 관찰된다.

\section{6. 기도(air canal)}

피층(cortex)과 수(pith)를 구성하는 유조직 중 일부는 과 도하게 파괴되어 속이 빈 형태로 관찰되거나, 소실되어 빈 공간으로 남겨진다. 골풀속에서 발달하는 이러한 기도 (air canal or air space)는 존재 유무에 의해 크게 2가지로 세 분되었다.

\section{1) 존재형 (present)}

기도가 줄기의 일정부위에 발달하는 유형으로 발달 위 치에 따라 3 가지 형태로 나타났다.
(1) 수형(air canal in pith): 수를 형성하는 유조직이 소실 되어 수강(pith cavity) 형태로 나타나는 유형으로 구름골 풀(Fig. 1A), 실비녀골풀(Fig. 1B), 골풀(Fig. 3G), 푸른갯골 풀(Fig. $3 \mathrm{H})$ 등에서 관찰되었다. 골풀과 푸른갯골풀에서 관찰되는 기도는 수를 구성하는 유조직이 수강 형태로 발달되지 않고, 스펀지 형태로 발달하여 느슨하게 수를 채우고 있으며, 횡단면에서는 별모양(stellated) 형태로 관 찰되었다.

(2) 수피층형(air canal in pith and cortex): 백두실골풀 (Fig. 1C), 설령골풀(Fig. 1D), 대택비녀골풀(Fig. 1E), 눈비 녀골풀(Fig. 2D), 청비녀골풀(Fig. 2E), 비녀골풀(Fig. 2F), 갯골풀(Fig. $3 \mathrm{D})$, 검정납작골풀(Fig. $3 \mathrm{E})$, 참골풀 $(F i g .3 \mathrm{~F})$ 등 에서 관찰되는 기도는 수에서 수강 형태로 발달하였고, 피층 내에서는 엽록조직 및 유조직 내의 일부 유세포가 

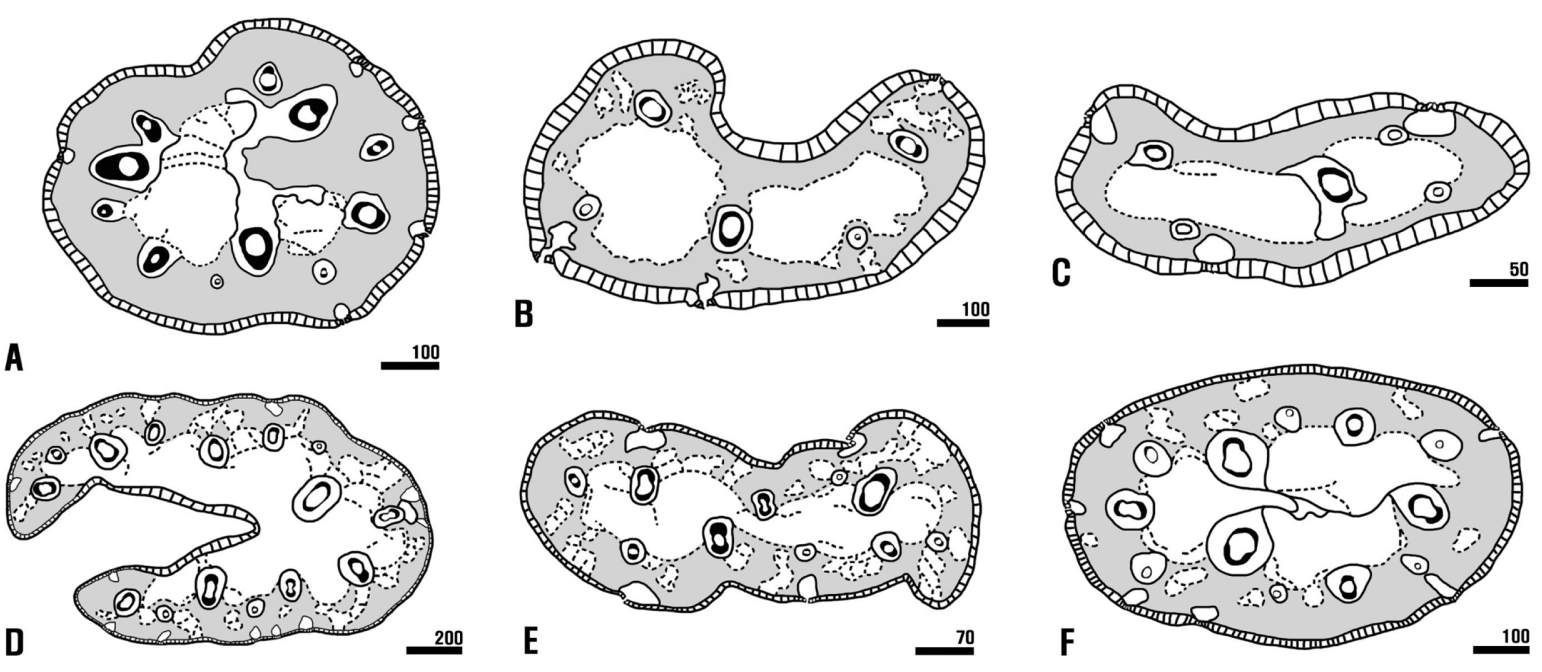

Fig. 4. Cross section shapes and structures of leaf in Korean Juncus. A-E. sect. Stygiopsis. A. J. triglumis. B. J. maximowiczii. C. J. potaninii. D. J. castaneus subsp. triceps (central part). E. J. castaneus subsp. triceps (apex). F. J. stygius subsp. americanus. Scale bar unit: $\mu \mathrm{m}$.

변형되어 나타나며, 피층 내에 산재하였다.

(3) 피층형 (air canal in cortex): 수는 기도가 발달하지 않 고 유세포로 채워져 있으며 피층 내 엽록조직과 유조직 에서 기도가 발달하는 유형으로 참비녀골풀(Fig. 2A), 날 개골풀(Fig. 2B), 별날개골풀(Fig. 2C), 애기골풀(Fig. 3A) 등에서 관찰되었다.

\section{2) 부재형(absent)}

길골풀(Fig. 3B)과 물골풀(Fig. 3C)에서는 유세포가 기 도로 발달하지 않고, 기능에 따라 엽록조직, 유조직, 수를 형성하였다.

\section{잎의 횡단면(cross section of leaf)}

갯골풀, 검정납작골풀, 골풀, 푸른갯골풀 및 참골풀 등 은 경생엽이 축소되어 줄기를 둘러싸는 초상의 인엽 (cataphyll)만을 형성하고 있으므로 엽신을 가진 잎과 비 교하기에는 무리가 있다. 따라서 본 연구에서는 이를 제 외하고, 엽신을 지니는 14 분류군만을 대상으로 해부학 적 형질을 관찰하였다. 잎은 향축면(adaxial surface)과 배 축면(abaxial surface)의 구분이 불가능한 단면엽과 가능 한 양면엽으로 크게 구분되었다(Figs. 4, 5, Table 2).

\section{1. 단면엽(unifacial leaf)}

발생적으로 한 면만을 갖는 잎이며, 단면이 원통상(구 름골풀, Fig. 4A; 실비녀골풀, Fig. 4B; 백두실골풀, Fig. 4C; 대택비녀골풀, Fig. 4F; 눈비녀골풀, Fig. 5D; 청비녀골 풀, Fig. 5E; 비녀골풀, Fig. 5F)이거나, 칼날모양(설령골풀, Fig. 4E; 참비녀골풀, Fig. 5A; 날개골풀, Fig. $5 \mathrm{~B}$; 별날개골 풀, Fig. $5 \mathrm{C}$ )으로서, 좌우면은 있으나 상하면은 구분되지
않았다. 유관속은 줄기에서처럼 잎 내부에 환상으로 배 열하며, 유관속 내측에 목부가 발달하고, 외측에 사부가 발달하는 병립유관속의 형태를 보이며, 주축유관속의 경 우 사부나 목부에서 섬유조직이 발달하여 섬유층이 유관 속을 둘러싸고 있는 형태로 관찰되었다. 또한 세포함유 물이 관찰되지 않는 유조직이 유관속을 환상으로 둘러싸 고 있으며, 세포함유물을 가지는 엽록조직의 세포층은 표피세포 아래에 다층으로 분포하였다.

\section{2. 양면엽(bifacial leaf)}

향축면과 배축면이 구분되는 잎의 형태로 애기골풀 (Fig. $5 \mathrm{G}$ ), 길골풀(Fig. $5 \mathrm{H}$ ), 물골풀(Fig. $5 \mathrm{I}$ ) 등에서 관찰되 었다. 양면엽을 지니는 분류군들의 향축면 표피세포는 배축면의 표피세포에 비해 크기가 크며, 기공이 발달하 지 않는 특징을 나타내었다. 또한 유관속은 향축면에는 목부가 배축면으로는 사부가 발달하여 일정한 방향성을 가지며, 엽육조직 내에 일렬로 배열하였다. 주축유관속 의 경우 목부섬유와 사부섬유가 발달하여 유관속 주위를 둘러싸고 있으며, 섬유세포의 무리가 엽신의 가장자리, 향축면으로 존재하고 있었다. 그리고 세포함유물이 관찰 되지 않는 유조직이 유관속을 환상(애기골풀, 물골풀) 또 는 일부(길골풀)를 둘러싸고 있었으며, 세포함유물을 가 지는 엽록조직의 세포층은 상하표피 아래에 다층으로 분 포하였다.

\section{잎의 종단면(longitudinal section of leaf)}

단면엽을 갖는 분류군들은 공통적으로 소관(canaliculus) 과 격막(septa)을 갖는 것으로 확인 되었으며, 이들의 발달 정도에 따라 3 가지 유형으로 구분되었다(Figs. 4, 5, 6, Table 2). 


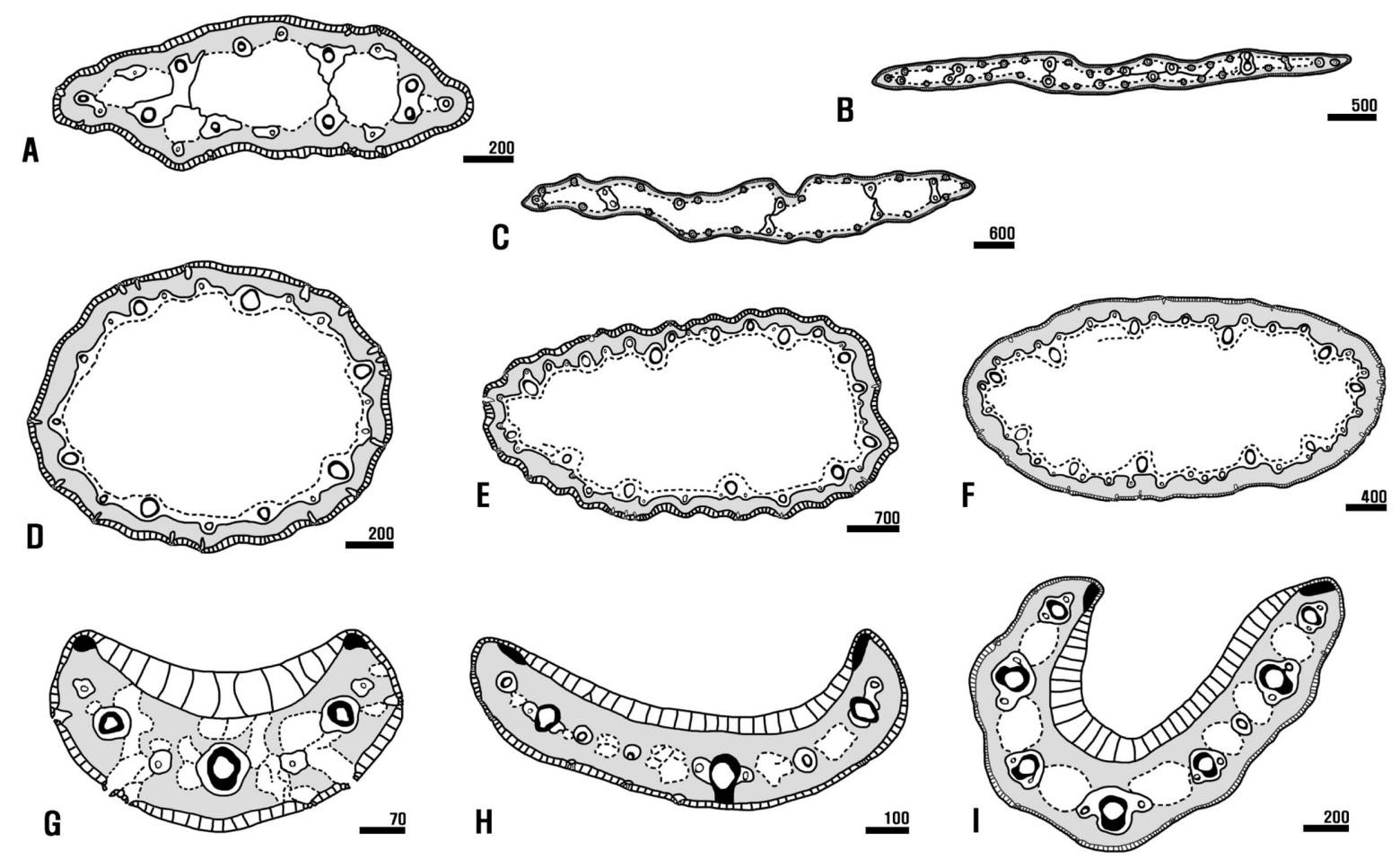

Fig. 5. Cross section shapes and structures of leaf in Korean Juncus. A-C. sect. Ozophyllum; D-F. sect. Iridifolii. G. sect. Tenageia. H, I. sect. Steirochloa, A. J. prismatocarpus subsp. leschenaultii, B. J. alatus, C. J. diastrophanthus, D. J. wallichianus, E. J. papillosus, F. J. krameri, G. J. bufonius, H. J. tenuis, I. J. gracillimus. Scale bar unit: $\mu \mathrm{m}$.

1. 이관질, 불완전 격막형(bitubular, imperfectly septate)

경생엽 내에는 2 개의 소관이 있으며, 격막은 소관을 완 전히 막지 않고, 하나의 소관만을 막고 있거나 소관의 일 부만을 격리하는 형태로 발달하는 유형으로, 구름골풀 (Fig. 4A), 실비녀골풀(Fig. 4B), 백두실골풀(Fig. 4C) 등에 서 확인되었다.

2. 다관질, 불완전 격막형(pluritubular, imperfectly septate) 경생엽 내에는 3 개 이상의 소관이 발달하며, 격막은 소 관을 완전히 격리하지 않고, 하나 또는 2 개 이상의 소관 만을 막고 있거나 소관의 일부만을 막고 있는 형태로, 설 령골풀(Fig. 4D, E), 대택비녀골풀(Fig. 4F), 참비녀골풀 (Fig. 5A, 6A), 날개골풀(Fig. 5B), 별날개골풀(Fig. 5C) 등 에서 관찰되었다.

3. 단관질, 완전한 격막형 (unitubular, perfectly septate)

경생엽 내부가 비어 있는 모양으로 온전한 1 개의 소관 이 발달하며, 격막은 소관을 완전히 격리하는 형태로, 눈 비녀골풀(Fig. 5D), 청비녀골풀(Fig. 5E, 6B), 비녀골풀 (Fig. 5F) 등에서 확인되었다.

\section{열매의 횡단면(Cross section of fruit)}

본 속의 열매는 삭과(capsule)로 3 개의 봉선(raphae)을
가지며, 성숙하여 포배열개(loculicidal)한다. 태좌(placenta) 기원의 격막 발달 정도에 따라 3 가지 유형으로 구분되었 다(Fig. 7, Table 2).

\section{1실형(unilocular)}

과벽의 태좌는 미약한 격막으로 발달하고, 과피의 측 벽에 거의 밀착하여 태좌의 좌우로 종자가 달리는 형태 로, 실비녀골풀, 날개골풀, 별날개골풀, 참비녀골풀, 눈 비녀골풀, 비녀골풀, 청비녀골풀(Fig. 7A) 등에서 관찰되 었다.

2. 가삼실 또는 3격막형(pseudo-trilocular or triseptate)

과벽의 태좌는 열매 반지름의 중간부까지 격막을 형성 하며, 태좌는 좌우로 확장되어 종자가 달리는 형태로, 구 름골풀, 설령골풀, 대택비녀골풀, 백두실골풀, 물골풀, 길 골풀(Fig. 7B), 갯골풀, 검정납작골풀, 푸른갯골풀, 참골 풀 등에서 관찰되었다.

\section{3실형(trilocular)}

과벽의 태좌는 열매의 중앙부까지 격막을 형성하여 자 방을 3 개의 방으로 나누며, 태좌는 좌우로 확장되어 종자 가 달리는 형태로 애기골풀과 골풀(Fig. $7 \mathrm{C}$ )에서 관찰되 었다. 


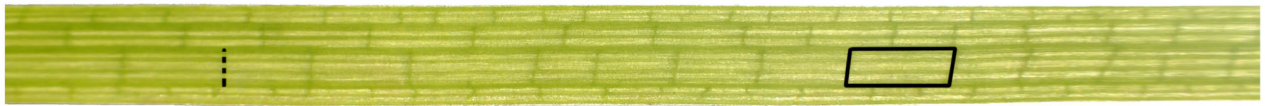

A

b

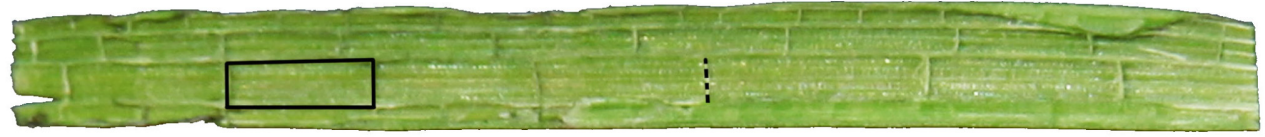

50

a

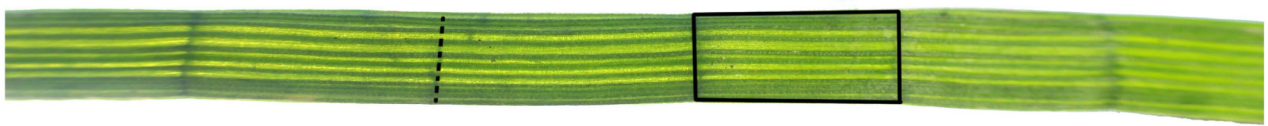

B

b

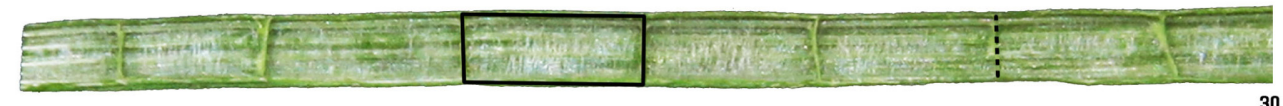

Fig. 6. Structures of leaf. A. J. prismatocarpus subsp. leschenaultii. B. J. papillosus. a, appearance of surface; b, longitudinal section of leaf. Scale bar unit: $\mu \mathrm{m}$. Septa (dotted lines); canaliculus (full lines).

\section{해부학적 형질에 근거한 한국산 골풀속의 검색표}

1. 뚜렷한 경생엽이 있으며, 단면엽이다(Subgenus Juncus).

2. 삭과의 횡단면은 원형 또는 아삼각형이며, 가삼 실이다(실비녀골풀은 단실)

Sect. Stygiopsis

3. 줄기의 기도는 수에만 존재한다.

4. 삭과의 횡단면은 아삼각형이고, 가삼실이다 .... 구름골풀 J. triglumis

4. 삭과의 횡단면은 원형이고, 단실이다

실비녀골풀 J. maximowiczii

3. 줄기의 기도는 수와 피층에 모두 존재한다.

5. 잎은 이관질이다 .... 백두실골풀 J. potaninii

5. 잎은 다관질이다.

6. 잎은 내권형이다

설령골풀 J. castaneus ssp. triceps

6. 잎은 아원통형이다

.* 대택비녀골풀 J. stygius ssp. americanus

2. 삭과의 횡단면은 명확한 삼각형이며 단실이다.

7. 줄기는 편평하고, 날개가 있다. 잎은 다관질에 불완전 격막을 갖는다

Sect. Iridifolii

8. 줄기의 수 내부에는 유관속이 발달하지 않 는다 ..... 참비녀골풀 J. prismatocarpus ssp. leschenaultii

8. 줄기의 수 내부에 산발적으로 유관속이 발 달한다.

9. 줄기에 발달하는 작은 유관속은 양쪽 날 개부위에만 존재한다 .. 날개골풀 J. alatus

9. 줄기에 발달하는 작은 유관속은 줄기 전 체에 고르게 분포한다

별날개골풀 J. diastrophanthus

7. 줄기는 원통형 또는 아원통형이고, 날개가 없 다. 잎은 단관질에 완전한 격막을 갖는다
Sect. Ozophyllum

10. 잎은 원통형이다

10. 잎은 아원통형이다.

눈비녀골풀 $J$. wallichianus

11. 줄기는 원통형이며, 잎에 세로 능선이 발달한다 ………청비녀골풀 J. papillosus

11. 줄기는 아원통이며, 잎은 평활하다

비녀골풀 J. krameri

1. 뚜렷한 경생엽이 없고 인엽만을 지니거나, 경생엽 이 있으면 양면엽이다(Subgenus Agathryon).

12. 양면엽인 경생엽을 지닌다.

13. 줄기의 피층에 기도가 존재하며, 삭과는 삼실 이다 .... Sect. Tenageia, 애기골풀 J. bufonius

13. 줄기에는 기도가 없으며, 삭과는 가삼실이다 ...

Sect. Steirochloa

14. 경생엽의 유조직은 소형의 유관속만 둘러 싼다 길골풀 $J$. tenuis

14. 경생엽의 유조직은 모든 유관속을 완전히 둘러싼다

물골풀 J. gracillimus

12. 경생엽이 없고, 소수의 인엽만을 갖는다

Sect. Juncotypus

15. 줄기의 표피 하부에는 후벽조직성의 섬유세 포가 없다.

16. 줄기의 유관속에 발달하는 섬유세포는 서 로 연결되어 환상으로 배열한다

갯골풀 J. heankei

16. 줄기의 유관속에 발달하는 섬유세포는 서 로 연결되어 있지 않고, 산발적으로 존재 한다 …….............. 검정납작골풀 J. fauriei

15. 줄기의 표피 하부에는 후벽조직성의 섬유세 포가 발달한다. 
17. 줄기의 기도는 수와 피층에 함께 있다 …..... 참골풀 J. filiformis

17. 줄기의 기도는 수에만 있으며, 스펀지 모 양이다.

18. 줄기에 미약한 세로 능선이 발달하고, 삭과는 삼실이다 ………골풀 J. decipiens

18. 줄기에 뚜렷한 세로 능선이 발달하고, 삭과는 가삼실이다

푸른갯골풀 J. setchuensis

해부학적 연구 결과 줄기의 유관속, 섬유, 기도의 배열 양상과 잎의 형태, 유관속 및 유조직의 배열양상, 삭과에 서 태좌의 발달정도 등의 형질들이 골풀속 식물의 분류 에 매우 유용한 것으로 확인되었다(Table 2). 특히 경생엽 의 존재 유무와 단면엽과 양면엽의 차이는 subg. Juncus와 subg. Aganthryon을 구분하는데 매우 중요한 형질이었으며, 이러한 형질은 각 꽃의 기부에 발달한 한 쌍의 소포가 없 는 subg. Juncus와 소포가 발달한 subg. Aganthryon을 분류 한 전통분류체계(Buchenau, 1906; Novara, 1976: Kirschner et al., 1999, 2002; Novikov, 2003)를 명확히 지지하였다. 또한 sect. Iridifolii의 경생엽에서 나타나는 단관질의 완전한 격 막을 지니는 특징 역시 sect. Stygiopsis 및 sect. Ozophyllum 의 경생엽에서 나타타는 이관질 및 다관질의 불완전한 격막을 지니는 특징과 대비되어 절을 분류하는 매우 유 용한 형질로 확인되었다. 따라서 sect. Iridifolii와 sect. Ozophyllum 을 동일한 분류계급으로 취급(Buchenau, 1906; Kreczetowicz and Gontscharov, 1935; Novikov, 2003) 하기보다는 별개의 분류계급으로 인정하는 것이 타당하 다고 판단된다(Balslev, 1996; Kirschner et al., 1999, 2002).

한편 진화경향성 측면에서 크게 단면엽과 양면엽으로 구분되는 잎의 형태는 양면엽에서 단면엽으로, 원형에서 편평한 형태로 진화하였을 것이라 추정되나 서로 다른 다계원적인 기원을 갖는다고 판단된다(Yamaguchi and Tsukaya, 2010; Nakayama et al., 2013). 또한 Buchenau (1906)는 형태형질을 기반으로 골풀과의 진화 경향성을 추측하였으며, 이에 따르면 골풀속 식물은 (1) 잎은 점점 편평해지고, (2) 잎에 격막이 형성되고, (3) 포와 자방 내 부의 소실을 중심으로 모든 기관의 축소화가 진행되었으 며, (4) 종자는 원형 또는 타원형으로부터 실모양으로 가 늘어졌고, (5) 화서의 측지는 점점 감소하는 추세로 분화
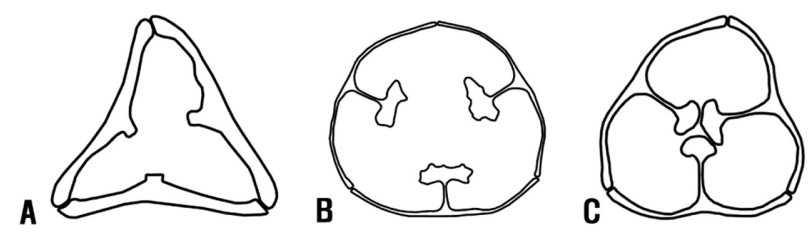

Fig. 7. Cross sections of fruit. A. Unilocular (J. papillosus). B. Pseudo-trilocular (J. tenuis). C. Trilocular (J. decipiens).
하였을 것이라고 언급한 바 있다(Drábková and Vlček, 2009).

Roalson (2005), Drábková et al. (2004, 2006), Drábková and Kirschner (2013) 등의 분자계통학적 연구에서는 골풀 속 내의 일부 절들이 다계통군을 형성하고 골풀속 내에 Oxychloë, Distichia, Luzula 등의 속들이 포함됨으로써 전 통적인 분류 체계를 재고할 필요성이 지속적으로 제기되 고 있다. 본 연구를 통해 관찰된 골풀속의 해부학적 형질 들은 일부 분류군에서 근연 분류군과의 분류형질로 유용 한 것으로 나타났지만, 종 수준 보다는 절 수준의 분류에 더 유용한 것으로 확인되었다. 따라서 다른 외부형태학 적 형질과 더불어 보다 객관적인 분류체계 설정에 기여 할 수 있을 것이라 판단된다.

\section{사 사}

본 연구는 2014년도 충북대학교 학술연구지원사업의 연구비 지원에 의해 수행되었습니다. 귀중한 표본을 대 여해주신 서울대학교 박종욱 교수님과 국립수목원 이정 심 박사님께 깊은 감사를 드립니다.

\section{Literature Cited}

Balslev, H. 1996. Juncaceae. Flora Neotropica Monograph 68: 1168.

Buchenau, F. 1875. Monographie der Juncaceen vom Cap. Abhandlungen Herausgegeben vom Naturwissenschaftlichen Vereine zu Bremen 4: 393-512.

Buchenau, F. 1890. Monographia Juncacearum. Botanische Jahrbücher für Systematik, Pflanzengeschichte und Pflanzengeographie 12: 1-495.

Buchenau, F. 1906. Juncaceae. Das Pflanzenreich IV 36: 1-284.

Chung, T. H. 1956. Korean Flora Vol. II. Sinjisa, Seoul, 1025 pp. (in Korean)

Chung, T. H. 1965. Juncaceae. In Illustrated Encyclopedia of Fauna and Flora of Korea, Vol. 5. Tracheophyta. Samwha, Seoul. Pp. 1299-1309. (in Korean)

Chung, T. H. 1970. Illustrated Encyclopedia of Fauna and Flora of Korea, Vol. 5. Tracheophyta (Appendix). Samwha, Seoul, 232 pp. (in Korean)

Cutler, D. F. 1969. Anatomy of the Monocotyledon, Vol. 4. Juncales. Oxford University Press, London, $357 \mathrm{pp}$.

Drábková, L., J. Kirschner, Č. Vlček and V. Pačes. 2004. TrnL$t r n \mathrm{~F}$ intergenic spacer and $t r n \mathrm{~L}$ intron define clades within Luzula and Juncus (Juncaceae): importance of structual mutations. Journal of Molecular Evolution 59: 1-10.

Drábková, L., J. Kirschner and Č. Vlček. 2006. Phylogenetic relationships within Luzula DC. and Juncus L. (Juncaceae): a 
comparison of phylogenetic signals of trnL-trnF intergenic spacer, $t r n \mathrm{~L}$ intron and $r b c \mathrm{~L}$ plastome sequence data. Cladistics 22: 132-143.

Drábková, L. Z. and Č. Vlček. 2009. DNA variation within Juncaceae: comparison of impact of organelle regions on phylogeny. Plant Systematics and Evolution 278: 169-186.

Drábková, L. Z. and J. Kirschner. 2013. Oreojuncus, a new genus in the Juncaceae. Preslia 85: 483-503.

Fernández-Carvajal, M. C. 1981. Revision del genero Juncus L. en la peninsula Iberica. I. Anales del Jardin Botanico de Madrid 38: 79-89.

Fernández-Carvajal, M. C. 1982a. Revision del genero Juncus L. en la peninsula Iberica. II. Anales del Jardin Botanico de Madrid 38: 417-467.

Fernández-Carvajal, M. C. 1982b. Revision del genero Juncus L. en la peninsula Iberica. III. Anales del Jardin Botanico de Madrid 39: 79-151.

Fernández-Carvajal, M. C. 1983. Revision del genero Juncus L. en la peninsula Iberica. IV. Anales del Jardin Botanico de Madrid 39: 301-379.

Fernández-Carvajal, M. C., R. Garcia and T. E. Diaz-González. 1989. Clave para la indentificación de las especies Ibéricas del género Juncus L. basada en caracteres anatómicos. Acta Botanica Malacitana 14: 89-104.

Jang, C. S. 2008. A taxonomy of the genus Juncus (Juncaceae) in Korea. Ms. thesis, Chungbuk National University, Cheongju, 96 pp. (in Korean)

Jang, C. S. 2016. A systematic study of the genus Juncus (Juncaceae) in northeastern Asia. Ph.D. dissertation, Chungbuk National University, Cheongju, 144 pp. (in Korean)

Kim, S. M. 2012. Phylogeny and classification of Juncus focused on Korean taxa. Ph.D. dissertation, Sungshin Women's University, Seoul, 196 pp. (in Korean)

Kim, S. M., Y. H. Cho, J. H. Kim, S. D. Shim and S. T. Kim. 2012. Juncus fauriei Lév. \& Vaniot (Juncaceae): a new record in Korea. Korean Journal of Plant Taxonomy 42: 330-334. (in Korean)

Kim, S. M and S. T. Kim. 2013. Diagnostic characters of Juncus (Juncaceae) species in Korea. Korean Journal of Plant Taxonomy 43: 196-207. (in Korean)

Kim, Y. S. and S. C. Ko. 1980. Distribution atlas of plants of Korea (III) atlas of Juncales in Korea. Korean Journal of Plant Taxonomy 10: 73-96. (in Korean)

Kirschner, J. et al. 2002. Species Plantarum: Flora of the World. Part 6, 7, 8: Juncaceae. Australian Biological Resources Study, Canberra, Part 6, 237 pp, Part 7, 336 pp, Part 8, 192 pp.

Kirschner, J. L. J. Novara, V. S. Novikov, S. Snogerup and Z. Kaplan. 1999. Supraspecific division of the genus Juncus (Juncaceae). Folia Geobotanica 34: 377-390.
Kreczetovich, V. I. and N. F. Gontscharov. 1935. Juncaceae. In Flora URSS (Flora Unionis Rerumpublicarum Sovieticarum Socialisticarum), Vol. 3. Komarov, V. L. (ed.), The Botanical Institute of the Academy of Sciences of the U.S.S.R., Leningrad. Pp. 504-576, 623-631.

Laharpe, J. J. C. 1825. Essai d'une monographie des vraies joncées. [Preprint read 18 March 1825 (with separate pagination 1-93) of paper published in Mémoires de la Société d'Histoire Naturelle de Paris 2, 3: 89-181 (1827)].

Lee, T. B. 1980. Illustrated Flora of Korea. Hyangmunsa, Seoul, 980 pp. (in Korean)

Lee, W. T. 1996a. Coloured Standard Illustrations of Korean Plants. Academy Publishing Co., Seoul, 855 pp. (in Korean)

Lee, Y. N. 1996b. Flora of Korea. Kyohak Publishing Co., Seoul, 1247 pp. (in Korean)

Léveillé, H. 1904. Nouveautés Chinoises, Coréennes et Japonaises. Bulletin de la Société Botanique de France 51: 289-292.

Linnaeus, C. 1973. Species Plantarum. Ed. 1. Juncus. Holmiae. Pp. 325-330.

Miquel, F. A. G. 1867. Prolusio Florae Japonicae. Annales Musei Botanici Lugduno-Batavi 3: 91-209.

Nakai, T. 1911. Flora Koreana II. Juncaceae. Journal of the College of Science, Imperial University of Tokyo 26: 226-269.

Nakai, T. 1952. A synoptical sketch of Korean flora. Juncaceae. Bulletin of the National Science Museum (Tokyo, Japan) 31: 128.

Nakayama, H., T. Yamaguchi and H. Tsukaya. 2013. Modification and co-option of leaf developmental programs for the acquisition of flat structures in monocots: unifacial leaves in Juncus and cladodes in Asparagus. Frontiers in Plant Science 4: 248.

Novara, L. J. 1976. Contribucion al conocimiento de las inflorescencias de Juncus y su significación taxonomica. Kurtziana 9: 41-61.

Novikov, V. S. 2003. Juncaceae. In Vascular Plant of The Russian Far East, I. Lycopodiophyta, Juncaceae, Poaceae (Gramineae). Kharkevich, S. S., N. S. Probatova and V. S. Novikov. (eds.), Science Publishers, Inc., Enfield, NH. Pp. 46-87.

Oh. S. Y. 1984. The Phytogeographical Studies of Juncaceae in Korea. Kyungpook National Uinversity, Bulletin of the Natural Science 37: 103-149. (in Korean)

Oh, Y. C. and C. S. Lee. 2007. Juncaceae. In The Genera of Vascular Plants of Korea. Flora of Korea Editorial Committee (ed.), Academy Publishing Co., Seoul. Pp. 1106-1112.

Palibin, J. 1901. Conspectus Florae Koreae III. Juncaceae. Trudy Imperatorskago S.-Peterburgskago Botaniceskago Sada 19: $116-117$.

Roalson, E. H. 2005. Phylogenetic relationships in the Juncaceae inferred from nuclear ribosomal DNA internal transcribed 
spacer sequence data. International Journal of Plant Sciences 166: 397-413.

Satake, Y. 1931a. Systematic and anatomical studies on the Japanese Juncaceae (1). Botanical Magazine 45: 235-249. (in Japanese)

Satake, Y. 1931b. Systematic and anatomical studies on the Japanese Juncaceae (2). Botanical Magazine 45: 446-453. (in Japanese)

Satake, Y. 1932. Systematic and anatomical studies on the Japanese Juncaceae (3). Botanical Magazine 46: 639-650. (in Japanese)

Satake, Y. 1933a. Icones of the Japanese Juncaceae (I). Journal of Japanese Botany 9: 286-297. (in Japanese)

Satake, Y. 1933b. Icones of the Japanese Juncaceae (II). Journal of Japanese Botany 9: 370-379. (in Japanese)

Satake, Y. 1933c. Icones of the Japanese Juncaceae (III). Journal of Japanese Botany 9: 417-424. (in Japanese)

Satake, Y. 1933d. Systematic and anatomical studies on the Japanese Juncaceae (2). Journal of the Faculty of Science, Univer- sity of Tokyo, Section III. Botany 4: 131-223.

Satake, Y. 1934. Icones of the Japanese Juncaceae (IV). Journal of Japanese Botany 10: 38-42. (in Japanese)

Satake, Y. 1938. Juncaceae. In Nova Flora Japonica vel Descriptiones et Systema Nova Omnium Plantarum in Imperio Japonico Sonte Nascentium, Vol. I. Nakai, T. and M. Honda (eds.), The Sanseido Co., Ltd., Tokyo and Osaka. Pp. 1-103. (in Japanese)

Wu, K. F. and S. E. Clemants. 2000. Juncaceae. In Flora of China, Vol. 24. Wu, Z. Y. and P. H. Raven (eds.), Science Press, Beijing and Missouri Botanical Garden Press, St. Louis, MO. Pp. 44-69.

Yamaguchi, T and H. Tsukaya. 2010. Evolutionary and developmental studies of unifacial leaves in monocots: Juncus as a model system. Journal of Plant Research 123: 35-41.

Yun, K. W., H. Jo and M. Y. Kim. 2014. A new species of Juncus (Juncaceae): J. baekdusanensis M. Kim. Korean Journal of Plant Taxonomy 44: 238-241. 